Article

\title{
Assessing the Potential of the Terrestrial Cyanobacterium Anabaena minutissima for Controlling Botrytis cinerea on Tomato Fruits
}

\author{
Hillary Righini $^{1}\left(\mathbb{D}\right.$, Ornella Francioso ${ }^{1}\left(\mathbb{D}\right.$, Michele Di Foggia $^{2}(\mathbb{D})$, Antera Martel Quintana ${ }^{3}(\mathbb{D})$ \\ and Roberta Roberti ${ }^{1, *}$
}

1 Department of Agricultural and Food Sciences, University of Bologna, Viale G. Fanin 40, 40127 Bologna, Italy; hillary.righini2@unibo.it (H.R.); ornella.francioso@unibo.it (O.F.)

2 Department of Biomedical and Neuromotor Sciences, University of Bologna, Via Irnerio 48, 40126 Bologna, Italy; michele.difoggia2@unibo.it

3 Banco Español de Algas, Instituto de Oceanografía y Cambio Global, IOCAG,

Universidad de Las Palmas de Gran Canaria, 35214 Las Palmas, Spain; amartel@marinebiotechnology.org

* Correspondence: roberta.roberti@unibo.it

check for

updates

Citation: Righini, H.; Francioso, O.; Di Foggia, M.; Martel Quintana, A.; Roberti, R. Assessing the Potential of the Terrestrial Cyanobacterium Anabaena minutissima for Controlling Botrytis cinerea on Tomato Fruits. Horticulturae 2021, 7, 210. https:// doi.org/10.3390/horticulturae7080210

Academic Editors: Igor Maksimov and Oksana Lastochkina

Received: 15 June 2021

Accepted: 21 July 2021

Published: 23 July 2021

Publisher's Note: MDPI stays neutral with regard to jurisdictional claims in published maps and institutional affiliations.

Copyright: (c) 2021 by the authors. Licensee MDPI, Basel, Switzerland. This article is an open access article distributed under the terms and conditions of the Creative Commons Attribution (CC BY) license (https:// creativecommons.org/licenses/by/ $4.0 /)$.

\begin{abstract}
Cyanobacteria are oxygenic phototrophs that have an essential role in soil $\mathrm{N}_{2}$ fixation, fertility, and water retention. Cyanobacteria are also natural sources of bioactive metabolites beneficial to improve plant vigor and potentially active against fungal plant pathogens. Therefore, we studied the antifungal activity of water extract (WE) and phycobiliproteins (PBPs) from Anabaena minutissima strain BEA 0300B against the fungal plant pathogen Botrytis cinerea on tomato fruits and in vitro. The water extract and PBPs were characterized by using FT-IR and FTRaman spectroscopies. Both water extract $(5 \mathrm{mg} / \mathrm{mL}$ ) and PBPs (ranged from 0.3 to $4.8 \mathrm{mg} / \mathrm{mL}$ ) reduced disease incidence and disease severity on tomato fruits and mycelium growth and colony forming units in vitro. For mycelium growth, a linear PBP dose-response was found. Tomato fruits were also characterized by FT-IR and FT-Raman spectroscopies in order to evaluate structural modifications induced by pathogen and PBP treatment. PBPs preserved cutin and pectin structures by pathogen challenge. In conclusion, A. minutissima can be considered a potential tool for future large-scale experiments for plant disease control.
\end{abstract}

Keywords: Botrytis cinerea; tomato; cyanobacteria; FT-IR; FT-Raman; aqueous extract; phycobiliproteins; biocontrol; antifungal activity

\section{Introduction}

Botrytis cinerea Pers., teleomorph Botryotinia fuckeliana (de Bary) Whetzel, is a worldwide Ascomycota pathogenic fungus with a necrotrophic lifestyle causing grey mold disease on a vast number of plant species. Based on its scientific and economic importance, B. cinerea is ranked second in the world Top 10 fungal plant pathogens list [1], affecting 586 genera, including several vegetables and fruits [2], such as tomatoes in the field, greenhouse, and during post-harvest $[3,4]$.

Tomato red ripe fruits are highly susceptible to grey mold disease; indeed, in this ripening stage, $B$. cinerea produces many toxins, cell wall degrading enzymes (CWDEs), reactive oxygen species (ROS), and other virulence factors that induce rapid death and decay of the fruit tissues $[5,6]$. Fruit infection by $B$. cinerea originates in the field, and the disease can remain quiescent for some time in tissues until favorable conditions allow sporulation and spread. Botrytis cinerea can be present in a broad range of environmental conditions [7], such as cold temperatures in the fridge, where it can grow successfully. During post-harvest, the spread of fungus infections is promoted by an abundant production of aerial mycelia and spores. Under suitable environmental conditions such as high 
humidity, free moisture on fruit surfaces and moderate temperatures, spores can germinate, developing a grey mycelium that makes the fruits non-marketable and edible.

Nowadays, the application of synthetic fungicides is the most efficient option for the control of grey mold during tomato cultivation. However, their use is a major concern for both human health and environmental safety that are the purpose of the European Regulation 1107/2009 and the Directive 2009/128. Therefore, following the principles of integrated pest management, these rules prioritize nonchemical and natural alternatives wherever possible for plant disease control.

Alternative pest management practices are gaining increased attention as organic agricultural practices are of increasing interest. In particular, the use of cyanobacteria and other microbes are of interest as they are a source of bioactive metabolites, including antibiotics or antimicrobials [8-11]. Cyanobacteria are prokaryotes that occur in various environments such as fresh and brackish water, oceans, soil, and glaciers. They are autotrophic microorganisms able to photosynthesize and make symbioses with plants and lichens [12]. In agriculture, they are mostly known for their nitrogen fixation capacity and for their plant biostimulant activities, but few studies have examined their antifungal activity against fungal plant pathogens. For example, on the tomato plant, substrate application of new cultures of A. variabilis and A. laxa showed efficacy against plant wilt caused by F. oxysporum f.sp. lycopersici [13]. In addition, an aqueous extract from $A$. minutissima (formerly named Anabaena sp.) inhibited B. cinerea growth in vitro [14] and reduced infected areas by Podosphaera xanthii, and fungal sporulation on cucumber detached cotyledons and seedlings by inducing the expression of several PR genes correlated to plant-induced resistance [15]. Furthermore, several species of Anabaena also showed antifungal activity against other plant pathogens such as Alternaria solani, Fusarium moniliforme, Pythium aphanidermatum, P. debaryanum, and Rhizoctonia bataticola $[16,17]$.

Among cyanobacterial bioactive compounds, the authors in [18] reported that phycobiliproteins extracted from Arthrospira platensis controlled gray mold disease on tomato fruit and fungal mycelial growth and spore germination in an artificial substrate. In addition, polysaccharides from Anabaena minutissima applied on strawberry fruits in pre-harvest reduced fruit infected area and pathogen sporulation [14].

Enhancement of non-destructive analytical techniques, such as spectroscopic methods, are key objectives for quantifying the severity of stress or disease in plants and crops. FT-IR and FT-Raman techniques are classified as vibrational spectroscopies. Both techniques are sensible to chemical bonds, which can vibrate by changing the bond length (stretching vibrations, indicated by the Greek letter $v$ ) or changing the bond angle (bending vibrations, indicated by the Greek letter $\delta$ ). The energy of vibrations (measured in $\mathrm{cm}^{-1}$ ) is typical of each chemical functional group, thus allowing a qualitative identification of chemical compounds. The difference between the two techniques relies on the physical mechanism of interaction between light and matter: FT-IR is an absorption technique; therefore, the bands in the spectrum correspond to frequencies absorbed by the sample. On the other side, Raman spectroscopy is an emission technique in which the bands in the spectrum correspond to the inelastic scattering of monochromatic radiation (generated by a laser source): the frequency of each band again corresponds to functional groups. These differences allow the techniques to be complementary [19].

Under these considerations, this research aimed to study: (i) the chemical structure of water extract (WE) and phycobiliproteins (PBPs) from the cyanobacterium Anabaena minutissima by using FT-IR and FT-Raman spectroscopies, (ii) the antifungal activity against Botrytis cinerea on tomato fruits and in vitro; and (iii) the structural changes in the fruit cell wall and pulp components as a consequence of PBP treatment.

\section{Materials and Methods}

\subsection{Anabaena minutissima Cultivation}

Anabaena minutissima (Lemmermann, 1898) BEA 0300B, isolated from a coastal humid basaltic wall in Ajuy, Gran Canaria, Spain, by the Spanish Bank of Algae BEA (Canary 
Islands, Spain), was cultivated outdoors at the BEA greenhouse facilities in polypropylene open tanks (90 L) with BG11 media [20] under continuous aeration supplied with $\mathrm{CO}_{2}$ pulses at a rate of 1 min every hour (Figure S1). Growth was monitored daily by measuring optical density at $680 \mathrm{~nm}$ in a spectrophotometer. Maximum irradiance levels reached $1800 \mu \mathrm{mol}$ photon $\mathrm{m}^{-2} \mathrm{~s}^{-1}$, and the water temperature fluctuated between 20 and $24{ }^{\circ} \mathrm{C}$. Weekly, the biomass was harvested by filtration, washed with distilled water, and dehydrated using a B. Master Plus dehydrator (Tauro Essicatori).

\subsection{Water Extract, Phycobiliproteins, and Pathogen}

Dried biomass of $A$. minutissima was used for water extract (WE) preparation and phycobiliproteins (PBPs) extraction. For WE, the biomass was suspended in sterile distilled water in a beaker at $5 \mathrm{mg} / \mathrm{mL}$ concentration under continuous stirring at $50{ }^{\circ} \mathrm{C}, 300 \mathrm{rpm}$ magnetic stirrer with heater (Arex Digital, Velp Scientifica, Italy). After $12 \mathrm{~h}$, the solution was filtered through a Whatman sterile filter paper, grade 1, particle retention $11 \mu \mathrm{m}$ [21]. PBPs were extracted by suspending $7.5 \mathrm{~g}$ of dried biomass in $100 \mathrm{~mL}$ of phosphate buffer $0.2 \mathrm{M}, \mathrm{pH}=7$ [18]. The suspensions were stirred for $4 \mathrm{~h}$ at room temperature in the dark and then centrifuged for $20 \mathrm{~min}$ at $13^{\circ} \mathrm{C}, 5000 \mathrm{rpm}$. The PBPs were desalted and separated from the cyanobacterial cell residues using Amicon ${ }^{\circledR}$ Ultra-4 (Millipore Corporation, Burlington, MA, USA) centrifugal filtering devices. Water extract and PBPs were then filtered with a GV Millex ${ }^{\circledR}$ Syringe Filter Unit (pore diameter $0.45 \mu \mathrm{m}$, Millipore Corporation, Burlington, MA, USA). After purification, PBPs and WE were lyophilized and subsequently stored at $-80{ }^{\circ} \mathrm{C}$ until use.

Botrytis cinerea 06 belongs to the DISTAL collection, and it was previously isolated from tomato fruits showing grey mold symptoms. The pathogen was maintained on potato dextrose agar (PDA, $4 \%$, Difco, Laboratories, Detroit, MI, USA) at $25^{\circ} \mathrm{C}$ until use.

\subsection{Antifungal Activity of WE and PBPS against B. cinerea on Tomato Fruit}

Tomato fruits Cherry of Pachino (Moncada, Soc. Agr. Coop. O.P., Ispica (RG), Italy) were firstly surface sterilized by immersion in a solution of sodium hypochlorite $(2.5 \%, v / v)$ for $3 \mathrm{~min}$. Then, fruits were rinsed three times in sterile distilled water and air-dried under a sterile flow cabinet. Five fruits were placed in plastic boxes on wet sterilized paper and wounded ( $5 \mathrm{~mm}$ deep) for treatment and pathogen inoculation on the blossom end with a sterile needle [18]. Ten $\mu \mathrm{L}$-drop of WE $(5 \mathrm{mg} / \mathrm{mL})$ or PBPs at the concentrations of $0.3,0.6,1.2,2.4$, and $4.8 \mathrm{mg} / \mathrm{mL}$ was pipetted in each wound, and $30 \mathrm{~min}$ after treatment, a $10 \mu \mathrm{L}$-drop of spore suspension $\left(10^{6}\right.$ spores $\left./ \mathrm{mL}\right)$ was inoculated. Fruits treated with sterile distilled water and inoculated with spore suspension were considered as the negative control. Fruits treated with $20 \mu \mathrm{L}$-drop of sterile distilled water were used for positive control. Three boxes $(n=3)$ were considered for each treatment and control. The boxes were closed in plastic bags to maintain the humidity, and they were incubated at $24{ }^{\circ} \mathrm{C}$ in a growth chamber with a $12 \mathrm{~h} / 12 \mathrm{~h}$ day/night photoperiod. Disease symptoms were evaluated after ten days as disease incidence and disease severity. For the disease incidence, diseased fruits were counted on the total of inoculated fruits. For disease severity, images of fruits with disease symptoms were taken, and the diseased area $\left(\mathrm{mm}^{2}\right)$ was measured with the software Image Processing and Analysis (ImageJ 1.51j8, National Institute of Health, Bethesda, MD, USA). Portions of fruits $(5 \times 5 \times 5 \mathrm{~mm})$ that received treatment, treatment and inoculation, and water (control) were sampled in the area of treatment/inoculation, then lyophilized and stored at $-80^{\circ} \mathrm{C}$ for processing with FT-IR and FT-Raman Spectroscopies. The experiment was repeated thrice under the same experimental conditions.

\subsection{Antifungal Activity of WE and PBPs against B. cinerea Colony Growth and Spore Germination}

The activity of WE and PBPs on fungal colony growth was assessed through the submerged colony technique [22]. Portions $(\varnothing 6 \mathrm{~mm})$ from the edge of a 14 day-old-colony were treated for $6 \mathrm{~h}$ at $24^{\circ} \mathrm{C}$ by immersion in a sterile test tube containing $1 \mathrm{~mL}$ of WE 
( $5 \mathrm{mg} / \mathrm{mL}$ ) and the PBPs at the five concentrations $(0.3,0.6,1.2,2.4$, and $4.8 \mathrm{mg} / \mathrm{mL})$. For the control, colony portions of $B$. cinerea were immersed in sterile distilled water. After treatment, colony portions were transferred in the center of Petri dishes on PDA medium and incubated at $24{ }^{\circ} \mathrm{C}$ in the dark. Three dishes $(n=3)$ were considered for each treatment and control. Fungal colony growth was measured daily along two mutually perpendicular diameters. The experiment was repeated thrice under the same experimental conditions.

The activity of WE and PBPs on spore germination was carried out by preparing in a sterile test tube a mixture of the WE, PBPs at each concentration or water (control) and a spore suspension of $B$. cinerea at the final concentration of $10^{5}$ spores $/ \mathrm{mL}$. From each mixture, $20 \mu \mathrm{L}$ were taken and gently spread on PDA medium in a Petri dish. Three dishes $(n=3)$ were considered for each treatment and the control. Dishes were incubated at $24{ }^{\circ} \mathrm{C}$ in the dark, and, after $48 \mathrm{~h}$, the CFU number was counted.

\subsection{FT-IR and FT-Raman Spectroscopies}

FT-IR spectra of WE, PBPs, and portions of lyophilized fruits (control, infected control, and treated with PBPs) were performed by using a Bruker Tensor FT-IR instrument (Bruker Optics, Ettlingen, Germany) provided with an accessory for analysis in total reflectance attenuated (ATR), single reflection, and angle of $45^{\circ}$ angle of incidence (Specac Quest ATR, Specac Ltd., Orpington, Kent, UK). The spectra were acquired from 4000 to $400 \mathrm{~cm}^{-1}$, with a spectral resolution of $4 \mathrm{~cm}^{-1}$ and 32 scans. In addition, background spectra against air were recorded under the same conditions before each sample. In an effort to highlight major structural changes, fruit spectra with the highest dose of PBP are presented and discussed.

By considering the fruits' analyses, each piece of fruit was placed on the diamond crystal fixed on a flat platform and pressure was applied by a compression clamp. Isopropyl alcohol was used for cleaning the diamond crystal before each measurement. Measurements were taken at five spots on both the outer and inner sides, and then the spectra of each side were averaged. Spectra were processed using the Grams/386 spectroscopic software (version 6.00, Galactic Industries Corporation, Salem, NH, USA).

The region from 1800 to $1500 \mathrm{~cm}^{-1}$ was resolved using a peak fitting analysis with the Grams/386 software (version 6.00, Galactic Industries Corporation, Salem, NH, USA). The bands were resolved with Gaussian functions, and the best-fit parameters were achieved by minimizing the reduced Chi-square. Good agreement between experimental and calculated profiles was obtained, with coefficients of determination, ranging from 0.990 to 0.980 and the standard error, $\mathrm{SE}$, from 0.001 to 0.005 . All data are expressed as percentage areas.

FT-Raman spectra were performed by using Bruker MultiRam FT-Raman spectrometer equipped with a cooled Ge-diode detector. The excitation source was an $\mathrm{Nd}^{3+}$-YAG laser $(1064 \mathrm{~nm})$ in the backscattering $\left(180^{\circ}\right)$ configuration. The focused laser beam diameter was about $100 \mu \mathrm{m}$, the spectral resolution $4 \mathrm{~cm}^{-1}$, and the laser power at the sample about $100 \mathrm{~mW}$. Each Raman spectrum was an average of 5000 spectra.

\subsection{Statistical Analysis}

All experiments were arranged in a complete randomized design. Data obtained with WE were analyzed with $\mathrm{t}-\mathrm{Student}$ test $(p<0.05)$; data obtained with PBPs were analyzed by ANOVA, and, if the $p$-value was less than 0.05 , means were separated by Tukey's test $(p<0.05)$. Percentage data of disease incidence for both WE and PBPs were arcsine transformed before analysis. A dose-response curve was calculated and slopes were compared for the effect of different doses of PBPs on colony growth over time. All analyses were performed with GraphPad Prism software, San Diego, CA, USA, v. 4.03, 2005.

\section{Results}

3.1. Antifungal Activity of WE and PBPs against B. cinerea on Tomato Fruit

Figure 1 shows the effect of tomato fruit treatment with WE on gray mold disease. Treatment significantly reduced disease incidence by $18.8 \%$ (Figure 1a) and severity 
by $14.0 \%$ (Figure $1 \mathrm{~b}$ ) compared to the control. Likewise, disease reduction was also achieved by treating tomato fruits with PBPs (Figure 2). Most strikingly, all doses of PBPs significantly reduced disease incidence by $44.5 \%$ (Figure 2a) compared with the control. No relationship between doses and disease incidence and severity was shown. However, disease severity was significantly reduced by $40.8 \%$ at the $0.6 \mathrm{mg} / \mathrm{mL}$ dose, and also by $65.5 \%$ at $1.2-4.8 \mathrm{mg} / \mathrm{mL}$ (Figure $2 \mathrm{~b}$ ).

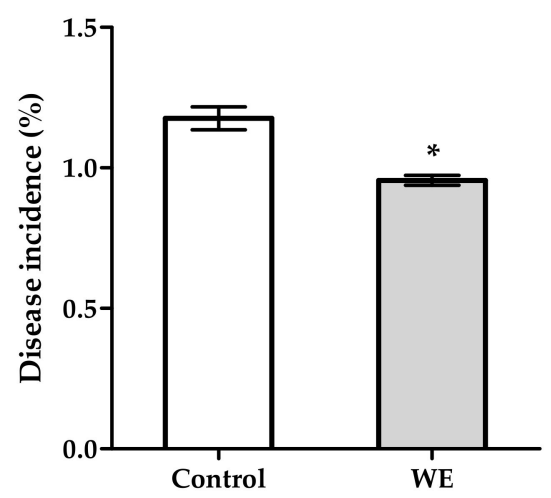

(a)

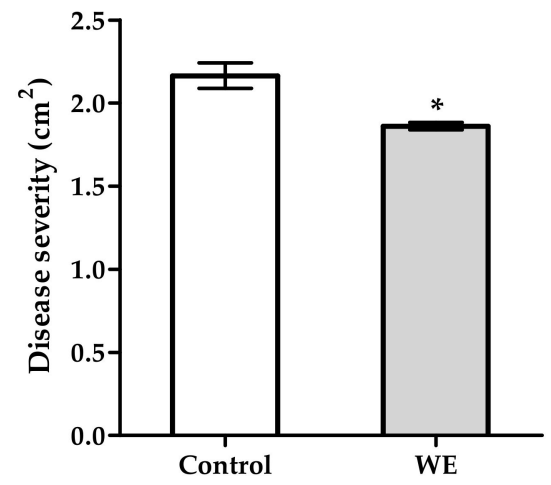

(b)

Figure 1. Activity of $5 \mathrm{mg} / \mathrm{mL}$ of water extract (WE) from Anabaena minutissima against disease incidence (a) and disease severity (b) caused by Botrytis cinerea on tomato fruit. Each value $(n=3)$ is expressed as mean $\pm \mathrm{SE}$. For disease incidence, data were arcsine transformed. For both disease incidence and disease severity, the asterisk indicates a significant difference of WE treatment with respect to untreated control according to the $t$-Student test, $p<0.05$.

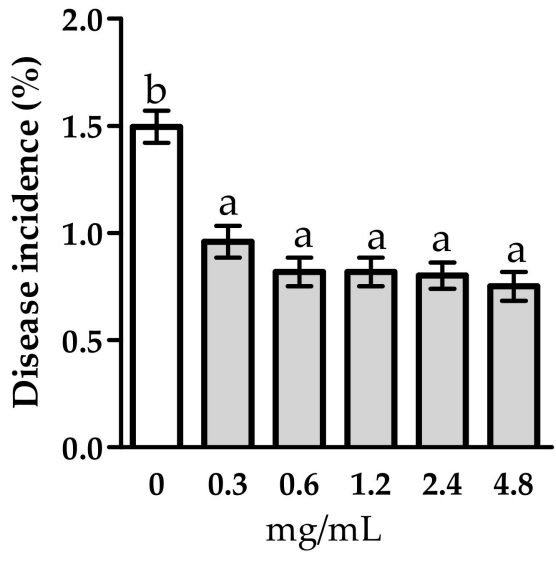

(a)

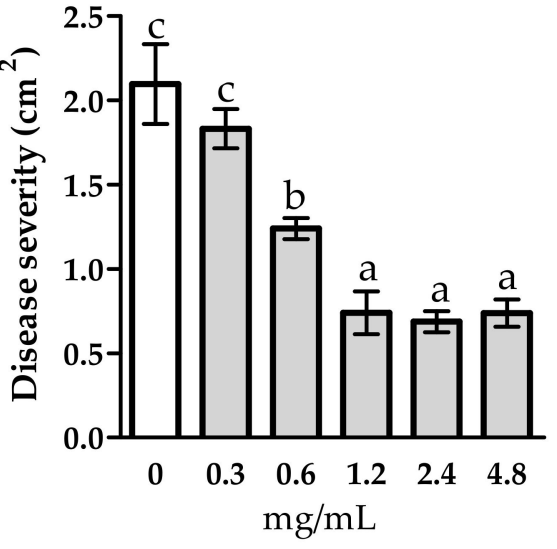

(b)

Figure 2. Activity of different concentrations of phycobiliproteins from Anabaena minutissima against disease incidence (a) and disease severity (b) caused by Botrytis cinerea on tomato fruit. Each value $(n=3)$ is expressed as a mean \pm SE. For disease incidence, data were arcsine transformed. Different letters indicate significant differences among treatments for both disease incidence and disease severity according to Tukey's multiple comparison test $(p<0.05), \mathrm{HSD}=0.21$ (a) and 39.85 (b).

\subsection{Antifungal Activity of WE and PBPs against B. cinerea Colony Growth and Spore Germination}

Botrytis cinerea colony growth was significantly reduced by WE on days 2, 3, and 4 after treatment (DAT) compared with the control (Figure 3). The different doses of PBPs reduced colony growth from 2 to 4 DAT (Figure 4a). We have found a linear fitting between doses and colony growth in each DAT (Figure $4 b-d$ ). The doses showed a different effect on colony growth in each DAT, as demonstrated by the statistical difference of the three slopes $\mathrm{F}_{(2,39)}=13.5945, p<0.0001$. Moreover, the Tukey's multiple comparison test revealed that the dose at the $4.8 \mathrm{mg} / \mathrm{mL}$ more efficiently reduced fungal growth than the control by $36.9 \%, 20.8 \%$, and $20.4 \%$ at 2,3 , and 4 DAT, respectively. 


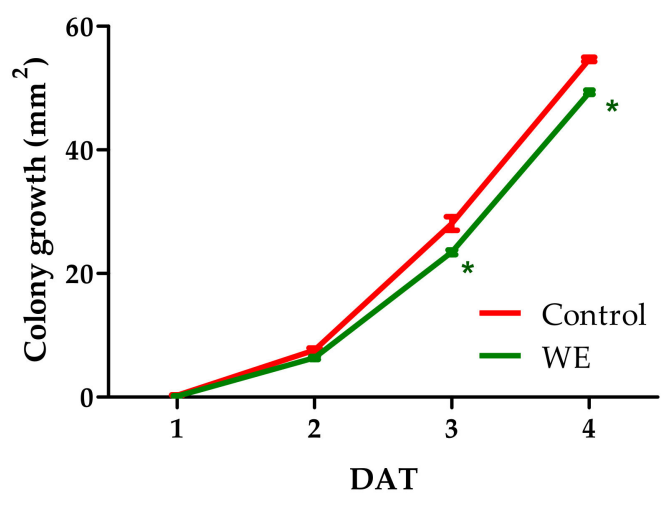

Figure 3. Activity of $5 \mathrm{mg} / \mathrm{mL}$ of water extract from Anabaena minutissima against Botrytis cinerea colony growth $\left(\mathrm{mm}^{2}\right)$ at $1,2,3$, and 4 days after treatment (DAT) on potato dextrose agar medium. Each value $(n=3)$ is expressed as a mean \pm SE. In each DAT, the asterisk indicates a significant difference of WE treatment with respect to untreated control, $t$-Student test, $p<0.05$.

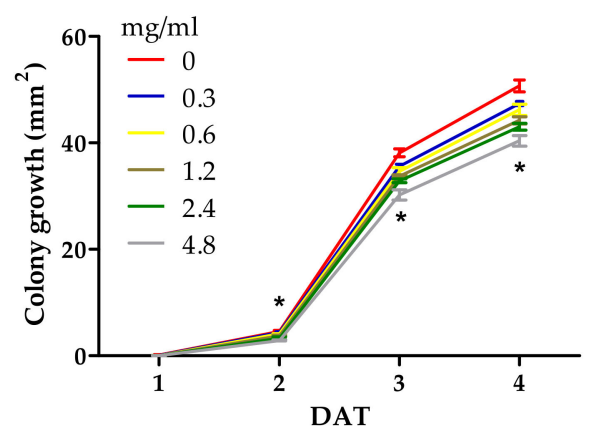

(a)

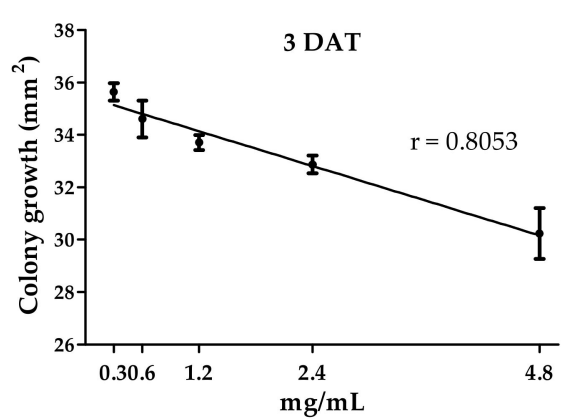

(c)

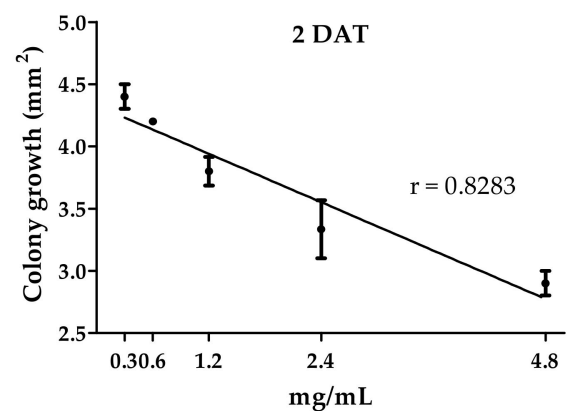

(b)

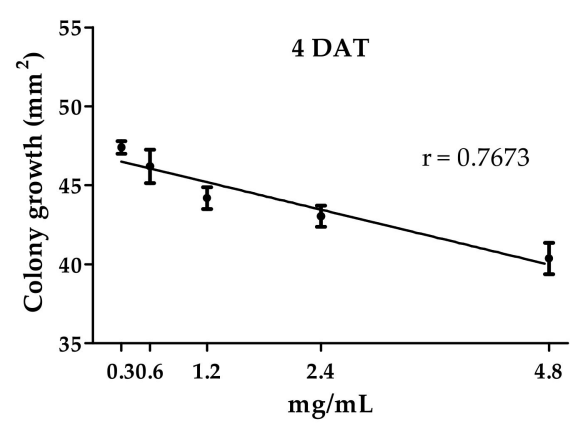

(d)

Figure 4. Activity of different doses of PBPs from Anabaena minutissima against Botrytis cinerea colony growth (mm ${ }^{2}$ ) at $1,2,3$, and 4 days after treatment (DAT) on potato dextrose agar medium (a) and linear regressions at 2 DAT (b) $\mathrm{y}=4.329-0.3239 \mathrm{x} ; p<0.0001$; 3 DAT (c) $\mathrm{y}=35.46-1.105 \mathrm{x} ; p<0.0001$; and 4 DAT (d) $\mathrm{y}=46.94-1.450 \mathrm{x}$; $p<0.0001$. Each value $(n=3)$ is expressed as a mean \pm SE. In each DAT $(\mathbf{a})$, the asterisk indicates a significant difference of each treatment with respect to untreated control, except for $0.3 \mathrm{mg} / \mathrm{mL}$ at 2 DAT, Tukey's test, $p<0.05$, $\mathrm{HSD}=0.41$ (2 DAT), 1.89 (3 DAT), and 2.65 (4 DAT).

The antifungal effect of WE and PBPs was also observed on spore germination evaluated as colony forming units (CFUs) per Petri dish area $\left(\mathrm{mm}^{2}\right)$ (Figures 5 and 6). The WE significantly reduced CFUs by $25.0 \%$ and $19.2 \%$ at 2 and 3 DAT, respectively, compared to the control (Figure 5). All PBP doses obtained a high CFUs reduction in both DATs (Figure 6). At 2 DAT, PBPs reduced CFUs by a range from $66.7 \%$ to $87.5 \%$ 
$(0.3 \mathrm{mg} / \mathrm{mL}-4.8 \mathrm{mg} / \mathrm{mL})$, while, at 3 DAT, all PBPs doses similarly reduced CFUs by an average of $55.5 \%$, towards the controls.

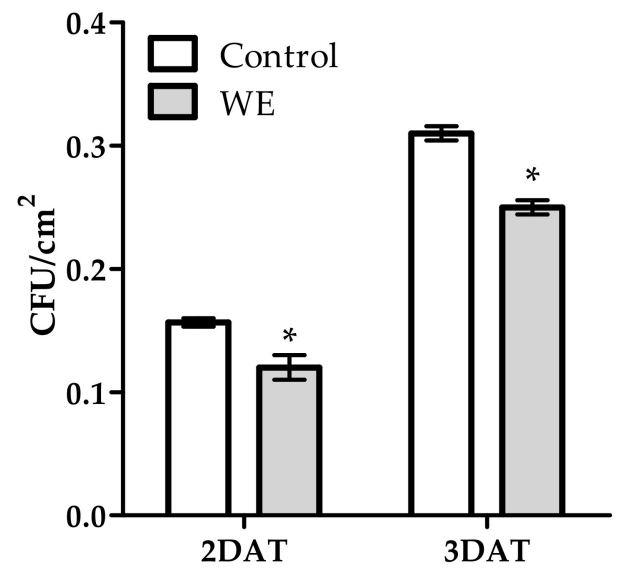

Figure 5. Activity of $5 \mathrm{mg} / \mathrm{mL}$ of water extract from Anabaena minutissima against Botrytis cinerea colony-forming units (CFU) at 2 and 3 days after treatment (DAT) on potato dextrose agar medium. Each value $(n=3)$ is expressed as a mean \pm SE. In each DAT, the asterisk indicates a significant difference with respect to untreated control, $t$-Student test, $p<0.05$.

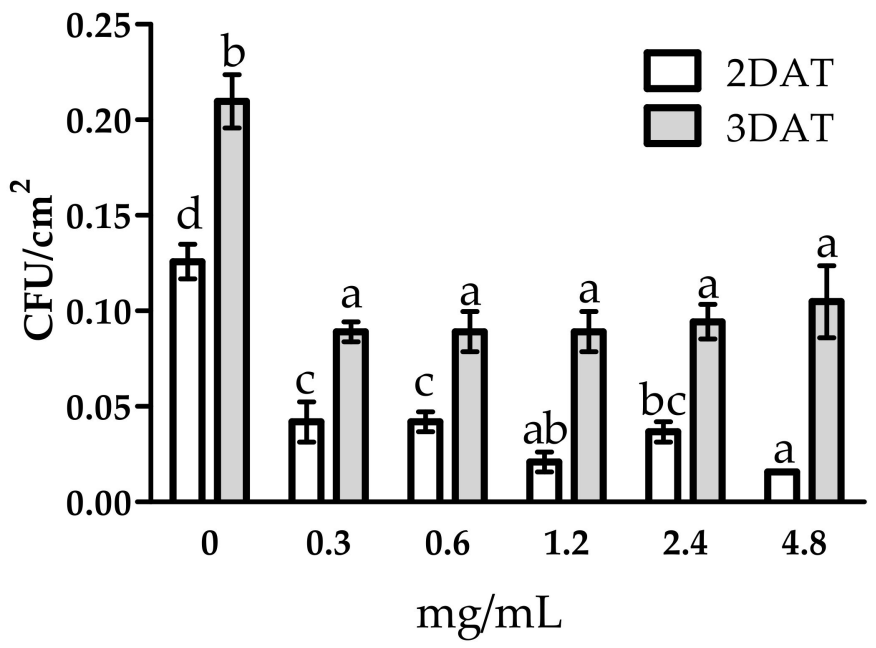

Figure 6. Activity of different doses of PBPs from Anabaena minutissima against Botrytis cinerea colony forming units (CFU) at two and three days after treatment (DAT) on potato dextrose agar medium. Each value $(n=3)$ is expressed as a mean \pm SE. In each DAT, different letters indicate significant differences among treatments and control according to Tukey's multiple comparison test $(p<0.05)$, $\mathrm{HSD}=0.02(2 \mathrm{DAT})$ and 0.04 (3 DAT).

Taken together, these results show that PBPs were more effective than WE and mainly against spore germination.

\subsection{FT-IR and FT-Raman Characterization of WE and PBPS}

FT-IR and FT-Raman spectroscopies were performed to identify the principal functional groups of PBPs and WE. As mentioned in paragraph 2.5, IR and Raman spectroscopies can give helpful information on the chemical composition of samples by studying the frequency of absorbed (in the case of IR) or scattered (Raman) radiation [19]. Each frequency can be attributed to a typical vibration of a functional group, i.e., $\mathrm{CONH}$ (amide) group in proteins. Based on their frequencies, Amide bands are classified with a progressive number (from Amide I around $1650 \mathrm{~cm}^{-1}$ to Amide V below $600 \mathrm{~cm}^{-1}$ ) and have a different intensity in the two techniques (i.e., Amide II band is visible in IR spectra while 
being absent in Raman). This last chemical group gives rise to different types of vibrations sensitive to the chemical environment, particularly the secondary structure adopted by proteins. The physical mechanism of interaction between light and matter in Raman spectroscopy (inelastic scattering) renders it very sensitive to aromatic (such as tyrosine amino acid) and conjugated (such as carotenoids) compounds.

The FT-IR spectra of PBPs and WE (Figure 7) showed specific functional groups of proteins [23,24]. Specifically, the shoulder at $3067 \mathrm{~cm}^{-1}$ is also known as Amide A, and it is typical in secondary amides [25]. The most prominent peaks at $1644 \mathrm{~cm}^{-1}$ and $1543 \mathrm{~cm}^{-1}$ are assigned to the Amide I and Amide II bands, respectively $[25,26]$. The other bands between $1249-1300 \mathrm{~cm}^{-1}$ are attributed to Amide III [25]. Secondary amides are also characterized by the presence of Amide V, at around $620 \mathrm{~cm}^{-1}$, Amide IV, and $535-600 \mathrm{~cm}^{-1}$ assigned to Amide VI. Moreover, the band at around $660 \mathrm{~cm}^{-1}$ may be assigned to the $-\mathrm{C} \equiv \mathrm{C}-\mathrm{H}$ stretching vibrations in alkynes [25]. PBPs and WE differed in the relative intensity of the amide bands, which were particularly stronger in PBPs (Figure 7 left).
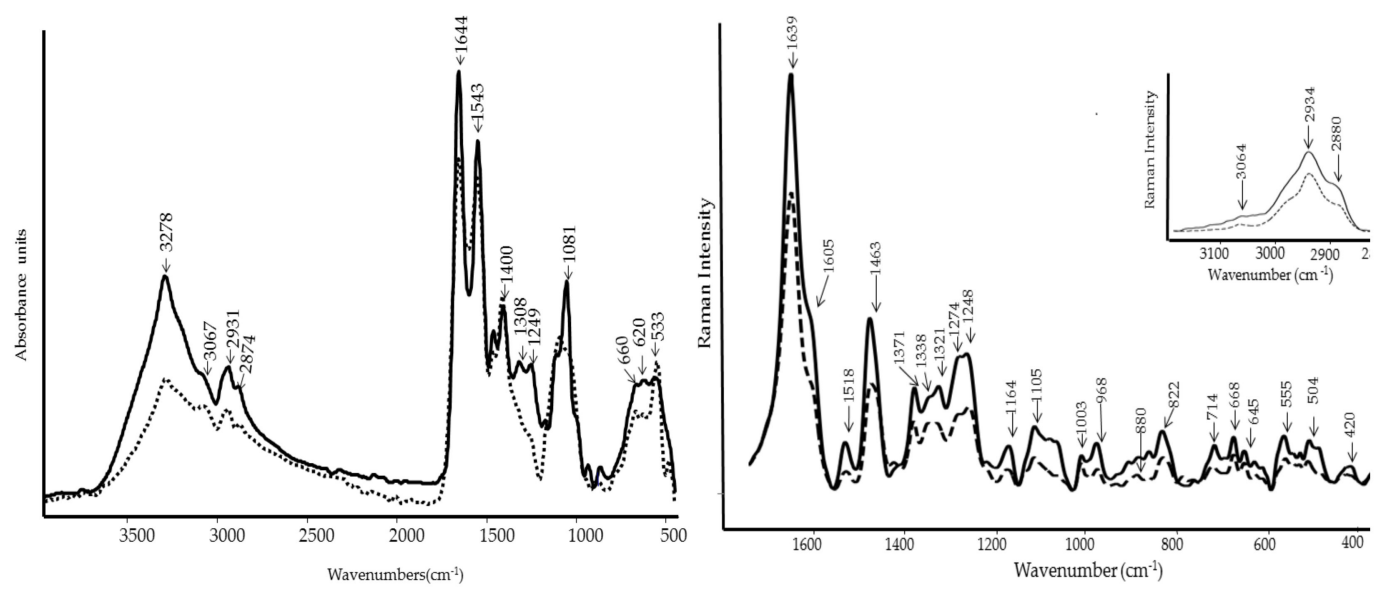

Figure 7. FT-IR (left) and FT-Raman (right) spectra of PBPs (line) and WE (dash) by Anabaena minutissima.

FT-Raman spectroscopy (Figure 7 right) confirmed that the main bands of PBP and WE are associated with proteins and conjugated compounds present as pigments in the alga [18]. In the $2800-3200 \mathrm{~cm}^{-1}$ spectral region, the 2934 and $2880 \mathrm{~cm}^{-1}$ peaks are attributed to aliphatic side chains and the $3064 \mathrm{~cm}^{-1}$ peak to aromatic amino acids. Other peaks typical of proteins are the following: $1639 \mathrm{~cm}^{-1}$ (amide I band), the shoulder at $1605 \mathrm{~cm}^{-1}$ (aromatic aminoacid such as Phe and Tyr), $1463 \mathrm{~cm}^{-1}$ (deformation of aminoacidic $\mathrm{CH}_{2}$ groups), 1371 and $1321 \mathrm{~cm}^{-1}$ (Trp bands), 1327 and $1105 \mathrm{~cm}^{-1}$ (CC and CN deformation bands) and 1248-1274 $\mathrm{cm}^{-1}$ (amide III band), and 822 and $645 \mathrm{~cm}^{-1}$ (Tyr bands). The amide bands gave interesting information about the secondary structure adopted by the algal proteins that is mainly helix/random as already observed in Hydropuntia cornea and Arthrospira platensis and further confirmed by the presence of the peaks at 1338 and $1105 \mathrm{~cm}^{-1}$ [27]. The typical bands of carotenoid pigments were detected at 1518, 1164, and $1003 \mathrm{~cm}^{-1}$ [18].

\subsection{FT-IR and FT-Raman Characterization of Tomato Fruits}

The spectra were performed on the 'fruits' outer and inner layers to detect possible structural changes. The prominent peaks present in the spectra of the outer side are associated with the main functional groups of the components of the cell wall of tomato (Figure 8). 


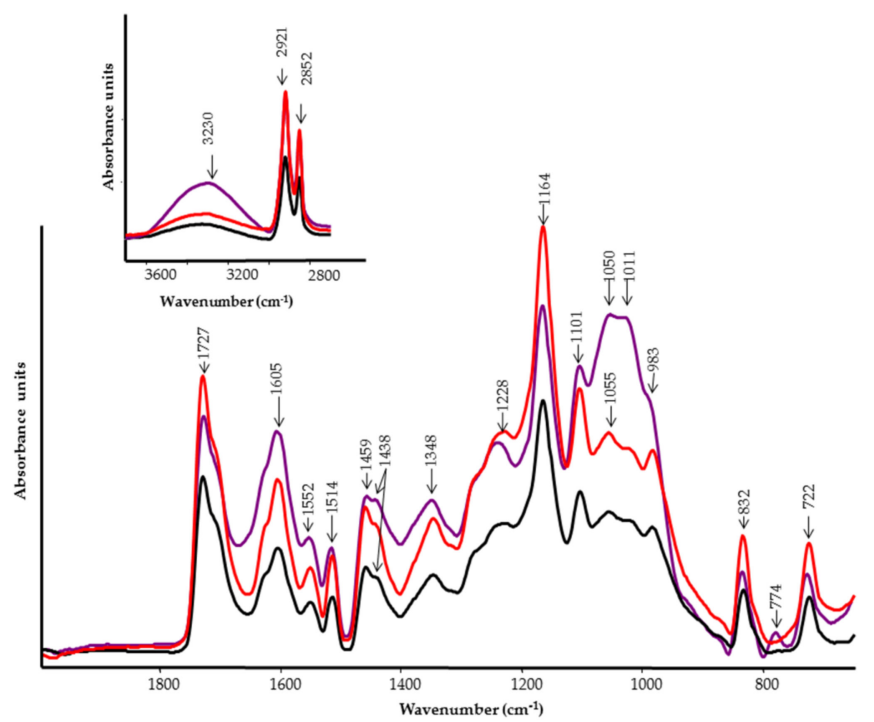

Figure 8. FT-IR spectra of the outer layer of tomato fruits. Black line, infected control; red line, control; violet line, treated with PBPs at $4.8 \mathrm{mg} / \mathrm{mL}$.

The first region of the IR spectra, displayed on the top of Figure 8, showed a broad band located at $3230 \mathrm{~cm}^{-1}$ that is assigned to the $\mathrm{OH}$ stretching vibration of polysaccharides and the nonesterified hydroxyl groups of cutin [28]. Two strong peaks at $2921 \mathrm{~cm}^{-1}$ and $2852 \mathrm{~cm}^{-1}$ are due to $\mathrm{CH}_{2}$ antisymmetric and symmetric stretching vibrations. Similar bands were observed in the Raman spectra at 2928 and $2860 \mathrm{~cm}^{-1}$ (Figure 9). These bands are coupled to the C-H deformation vibrations occurring at $1459 \mathrm{~cm}^{-1}\left(1457 \mathrm{~cm}^{-1}\right.$ in Raman) and $1438 \mathrm{~cm}^{-1}\left(1443 \mathrm{~cm}^{-1}\right.$ in Raman) of paraffinic chains. It is evident that the intensity of these bands increases with the number of methylene groups [25]. This is visible in the spectrum of PBP-treated tomatoes. Additionally, the band at $722 \mathrm{~cm}^{-1}$, attributed to $\mathrm{CH}_{2}$ rocking vibration, corroborates the presence of $n$-paraffins [25]. This band is also positively related to the number of methylene groups in the paraffin chains. The reduced intensity of the above bands in both the IR and Raman spectra of tomato with the pathogen suggests a change in the length of the methylene chains of cutin (Figure 8 , black line). Moreover, the weak band around $770 \mathrm{~cm}^{-1}$, appearing in the tomato spectrum treated with PBP, suggests that - $\left(\mathrm{CH}_{2}\right)_{4}$ - units are attached to oxygen or nitrogen [25]. Other bands associated with cutin are those of pectin at $1727 \mathrm{~cm}^{-1}(\mathrm{C}=\mathrm{O}$ stretching motion of alkyl ester), $1605 \mathrm{~cm}^{-1}$ (COO${ }^{-}$antisymmetric stretching in polygalcturonic acid), $1348 \mathrm{~cm}^{-1}$ $\left(\mathrm{COO}^{-}\right.$symmetric stretching), $1228 \mathrm{~cm}^{-1}$ (C-O stretching), $1164 \mathrm{~cm}^{-1}$ (C-O-C stretching in glycosidic bond and C-C stretching in pectin ring), $1101 \mathrm{~cm}^{-1}$ (C-O-C stretching, C-O stretching, $\mathrm{C}-\mathrm{C}$ stretching), $1050 \mathrm{~cm}^{-1}$ (C-O and $\mathrm{C}-\mathrm{C}$ stretching in uronic acid and neutral sugar), $1011 \mathrm{~cm}^{-1}$ (C-O and C-C stretching, pectin $\left.\mathrm{C}_{2}-\mathrm{C}_{3}, \mathrm{C}_{2}-\mathrm{O}_{2}, \mathrm{C}_{1}-\mathrm{O}_{1}.\right), 983 \mathrm{~cm}^{-1}(\mathrm{CO}$ bending), and $832 \mathrm{~cm}^{-1}$ (ring vibration) [29]. In the Raman spectra (Figure 9), the 1124 and the $1080 \mathrm{~cm}^{-1}$ bands are attributed to C-O-C stretching vibrations of polysaccharides, and the 1376 and $522 \mathrm{~cm}^{-1}$ bands to hemicellulose [30]. The band located in the $850-865 \mathrm{~cm}^{-1}$ spectral region (C-O-C stretching vibration) is diagnostic of the esterification degree of pectins: the shift from 855 (control) to $864 \mathrm{~cm}^{-1}$ (infected and PBP-treated) indicates a lower esterification degree. A higher pectin content in PBP-treated tomatoes can be inferred by the intensification of 1082, 822, 711, and $638 \mathrm{~cm}^{-1}$ Raman bands [31]. Significant intensification of the region between $900-1100 \mathrm{~cm}^{-1}$ can be seen in the tomato treated with PBP. Other bands observed at $1552 \mathrm{~cm}^{-1}$ (also observed in Raman) and $1514 \mathrm{~cm}^{-1}$ are assigned to different aromatic and $\mathrm{C}=\mathrm{C}$ chemical groups present in phenolic compounds $[32,33]$. In the Raman spectrum, other bands attributed to phenolic compounds appeared at 1605 and $1168 \mathrm{~cm}^{-1}$ [18]. The Raman spectra of the outer layer provided very little information about proteins' conformational changes: amide I band is almost absent in the $1630-1670 \mathrm{~cm}^{-1}$ spectral region, while the amide III band at $1269 \mathrm{~cm}^{-1}$ was a typical turn structure [27]. 


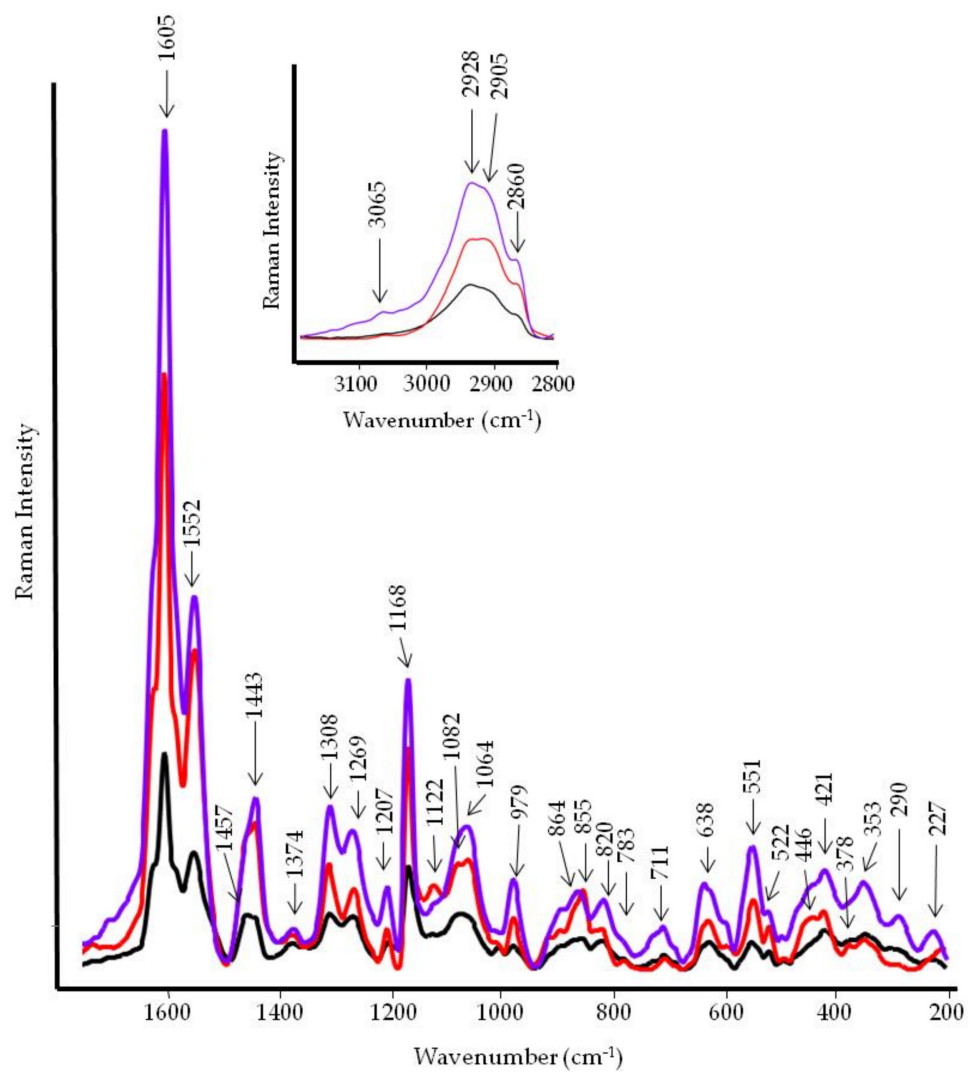

Figure 9. FT-Raman spectra of the inner layer of tomato fruits. Black line, infected control; red line, control; violet line, treated with PBPs at $4.8 \mathrm{mg} / \mathrm{mL}$.

The FT-IR spectra of inner layer pulp fruit identify the major functional groups of this component (Figure 10). In general, there is a similar pattern in the main functional groups already displayed in Figure 8. However, some differences are due to variations in relative intensity between the external and internal components of the tomato fruit. For instance, in pulp spectra, the peak at $3280 \mathrm{~cm}^{-1}$ (OH stretching) is more intense than at $2923 \mathrm{~cm}^{-1}$ and $2852 \mathrm{~cm}^{-1}$ (Figure 10, top).

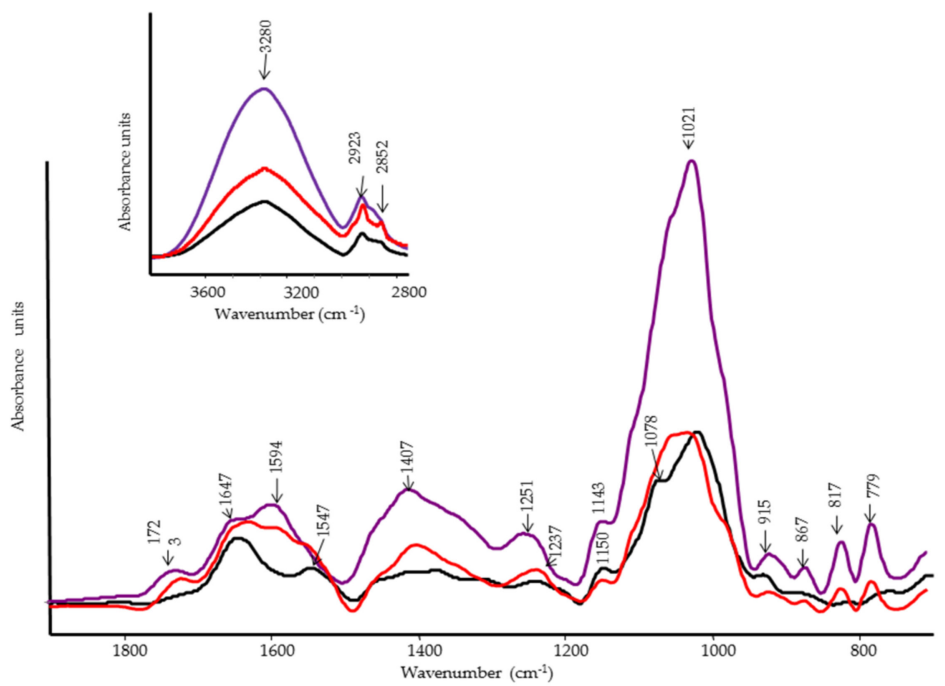

Figure 10. FT-IR spectra of tomato fruits pulp. Black line, infected control; red line, control; violet line, treated with PBPs at $4.8 \mathrm{mg} / \mathrm{mL}$. 
The low intensity of the methylene groups combined with the band's absence at $722 \mathrm{~cm}^{-1}$ would imply a lower paraffin chain content, further confirmed by the disappearance of the $2860 \mathrm{~cm}^{-1}\left(\mathrm{CH}_{2}\right.$ symmetric stretching $)$ and $1459 \mathrm{~cm}^{-1}$ bands in the Raman spectrum.

The band's appearance at $779 \mathrm{~cm}^{-1}$ in the control and in the PBP-treated tomato, meanwhile, indicates that the $-\mathrm{CH}_{2}$ - units are close to oxygen as already remarked on the outer side spectrum (Figure 10, violet line). In pulp, the bands assigned to pectin are: $1723 \mathrm{~cm}^{-1}, 1594 \mathrm{~cm}^{-1}, 1407 \mathrm{~cm}^{-1}, 1237 \mathrm{~cm}^{-1}, 1143-1150 \mathrm{~cm}^{-1}, 1021 \mathrm{~cm}^{-1}, 915 \mathrm{~cm}^{-1}$, and $867 \mathrm{~cm}^{-1}$ (rocking $\mathrm{CH}_{2}$ and bending in-plane $\mathrm{CH}$ ). The Raman bands of pectin appeared at $822,708,629$, and $345 \mathrm{~cm}^{-1}$ [31]. All of these bands are present in the control and PBP. In this last sample, the intensity is amplified, as in the Raman spectrum (Figure 11). A considerable structural modification in the pulp from the tomato infected (Figure 10, black line $)$ is observed. The bands at $1723 \mathrm{~cm}^{-1}\left(\mathrm{C}=\mathrm{O}\right.$ stretching of ester), $1595 \mathrm{~cm}^{-1}$ and $1407 \mathrm{~cm}^{-1}\left(\mathrm{COO}^{-}\right.$asymmetric and symmetric stretching, respectively), and $1237 \mathrm{~cm}^{-1}$ (C-O stretching) markedly decrease. Accordingly, the 'pectins' esterification degree marker band shifted from 855 to $862 \mathrm{~cm}^{-1}$ in the Raman spectrum, as previously observed in the outer layer.

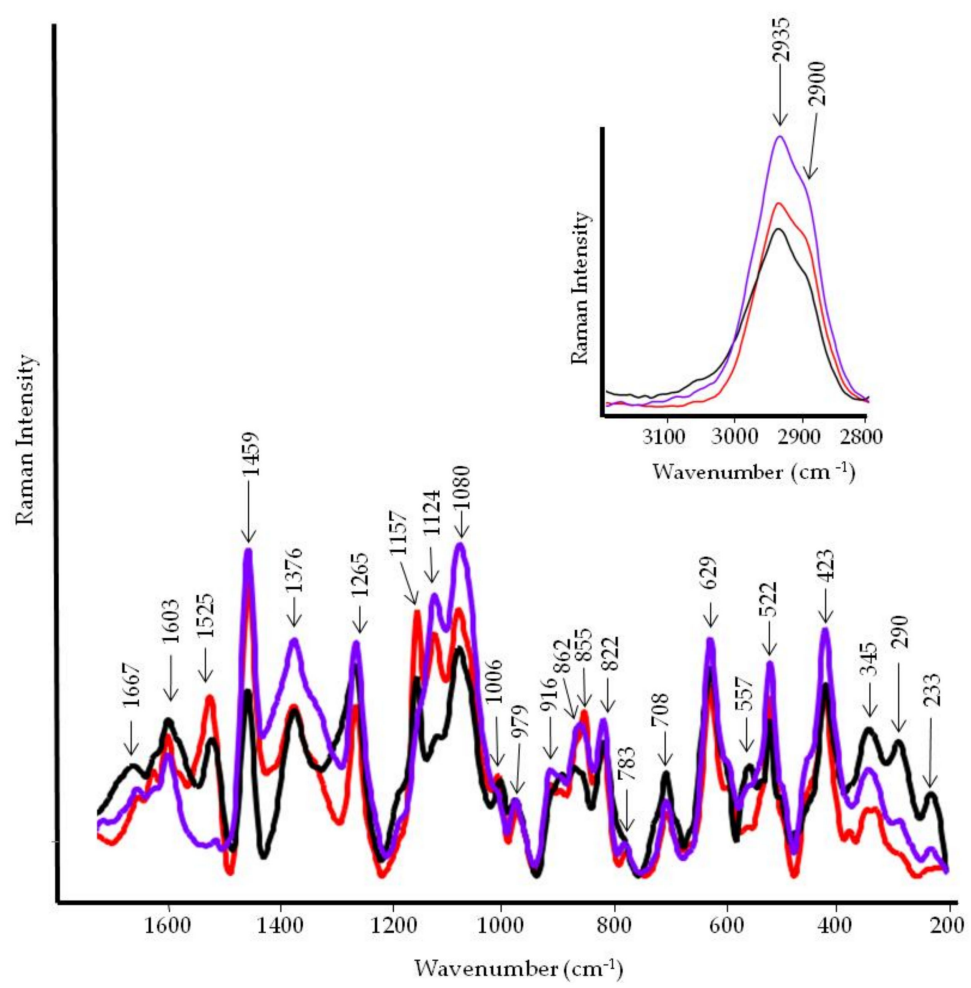

Figure 11. FT-Raman spectra of tomato fruit pulp. Black line, infected control; red line, control; violet line, treated with PBPs at $4.8 \mathrm{mg} / \mathrm{mL}$.

Other bands at $1647 \mathrm{~cm}^{-1}, 1547 \mathrm{~cm}^{-1}$, and $1250 \mathrm{~cm}^{-1}$ may be attributed to Amide I, Amide II, and Amide III, respectively. In the Raman spectrum (Figure 11), the Amide I band appeared at $1667 \mathrm{~cm}^{-1}$, while the Amide III at $1265 \mathrm{~cm}^{-1}$. Moreover, the aromatic ring vibration between $1650 \mathrm{~cm}^{-1}$ and $1500 \mathrm{~cm}^{-1}$ coupled with the band at $817 \mathrm{~cm}^{-1}$ (out-of-plane C-H bending) cannot be ruled out [28]. In the Raman spectrum, this finding was confirmed by the low intensity of the $1603 \mathrm{~cm}^{-1}$ band. Similarly, carotenoids bands at 1525,1157 , and $1006 \mathrm{~cm}^{-1}$ showed a reduced intensity and almost disappeared in the PBP treated tomato.

A Gaussian curve fitting procedure that applied to the region between $1500-1800 \mathrm{~cm}^{-1}$ of pulp provided more detailed spectral information (Figure 12). 

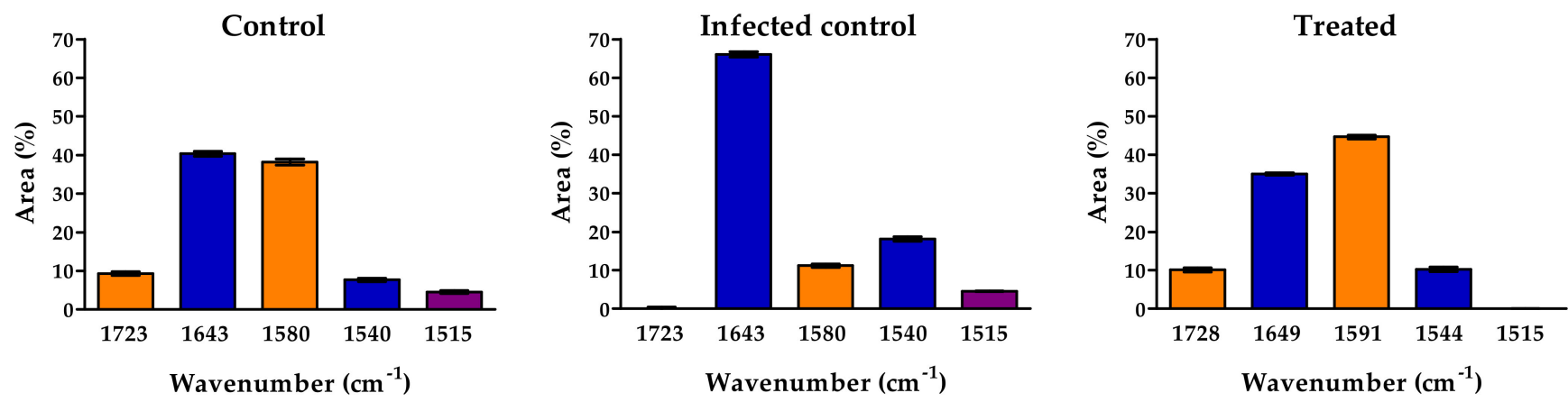

Figure 12. Area percentage of the bands in the region between 1800 and $1500 \mathrm{~cm}^{-1}$ of control, infected control and treated with PBPs. Each value $(n=3)$ is expressed as a mean \pm SE.

In tomato pulp control, the percentage area of pectin at $1723 \mathrm{~cm}^{-1}$ and $1580 \mathrm{~cm}^{-1}$ accounted for $9.3 \%$ and $38 \%$, respectively. In contrast, after infection, the percent area $\left(1587 \mathrm{~cm}^{-1}\right)$ decreased significantly to $11 \%$. With the highest dose of PBP pretreatment and subsequent infection, the pectin accounted for 10\% $\left(1728 \mathrm{~cm}^{-1}\right)$ and $45 \%\left(1591 \mathrm{~cm}^{-1}\right)$, respectively. As for protein, it amounted to $40 \%$ to $38 \%$ for amide I $\left(\sim 1640 \mathrm{~cm}^{-1}\right)$ and $8 \%$ to $10 \%$ for amide II $\left(\sim 1540 \mathrm{~cm}^{-1}\right)$ in the control and highest PBP pretreatment dose, respectively. In contrast, with infection, amide I was $66 \%$, and amide II was $18 \%$.

For phenolic compounds $\left(1515 \mathrm{~cm}^{-1}\right)$, the percentage area was $4.5 \%$ in control and infected plants. No band was detected in PBP treatment.

\section{Discussion}

The post-harvest losses of fresh tomato fruits are largely due to Botrytis spp. infections. Management of Botrytis cinerea is extremely complex, given the ability of this pathogen to infect the tomato crop in all parts of the plant. Economically, the losses are considerable because the value of fresh produce increases significantly as it is transferred from farm to fork [34].

Biocontrol is an appealing alternative or supplement to the conventional approaches for disease control. In addition, microbial biocontrol agents are recognized to be environmentally friendly, and their mode of action reduces the risk of resistance development. In that context, cyanobacteria are promising biocontrol agents of plant pathogens for their antimicrobial properties already shown on tomato, turnip, and strawberry [35-37].

This study examined the potential of water extract (WE) and PBPs from the terrestrial strain Anabaena minutissima against Botrytis cinerea artificially inoculated on tomato fruits.

WE and PBPs showed antifungal activity against the pathogen on fruits, CFUs, and mycelium. An earlier study demonstrated the effectiveness of the same WE against Podosphaera xanthii pathogen fungus on cucumber [15]. Its efficacy was correlated to a high content of several components such as proteins, PBPs, chlorophylls and carotenoid, and high antioxidant activity. Thereby, the protein content of WE was confirmed by FT-IR and FT-Raman spectroscopy (Figure 7). Other substances present in the form of carotenoid pigments were also associated with proteins [18]. Given the similarity between the FT-IR and FT-Raman spectra of WE and PBPs, it may be inferred that the protein component is only active against $B$. cinerea. The main variation may be related to the concentration being higher in PBPs. The effectiveness of PBPs by another cyanobacterium, Arthrospira platensis, against $B$. cinerea on tomato fruits was already shown [18]. The PBP antifungal activity of Synechocystis sp. and Arthrospira fusiformis against Candida albicans, a human fungal pathogen, was investigated [38]. How PBPs work against B. cinerea is a tricky question. PBPs of Anabaena minutissima have a typical helix-like structure, and they are the most abundant transmembrane proteins of the helix class [39]. It may be assumed that they interact with the fungal cell wall and consequently perturb the cellular activity, as was also assumed for PBPs of A. platensis [37]. The abundance of aromatic amino acids (Phe, Trp, 
and Tyr) implies that PBPs possess distinct hydrophobic and hydrophilic domains which interact differently with the cell wall of $B$. cinerea [37].

Interestingly, the antifungal activity against spore germination and mycelium growth was dose-dependent at 2,3, and 4 DAT. The greatest efficiency was achieved at the highest dose $(4.8 \mathrm{mg} / \mathrm{mL})$. The use of PBPs with antifungal activity to prevent and treat fungal infections opens new perspectives for biocontrol.

Micro ATR-FTIR and FT-Raman made it possible to examine the outer epidermal and inner pulp layers of tomato fruits in less than one $\mathrm{mm}$. Therefore, an overview of the biochemical changes in tomato fruits following treatments was provided. Both the IR and Raman spectra of the tomato with the pathogen showed significant changes in the outer layer regarding a decrease in the length of the cutin methylene chains (Figure 8). It is well established that cutin is the main component of the plant cuticle, covering external surfaces of herbaceous organs, including fruits [40]. The cuticle provides plant protection against abiotic and biotic stresses such as pathogenic fungal attack. It is degraded by cutinases considered pathogenicity factors for necrotrophic fungi that directly penetrate the host surface.

Interestingly, both techniques showed the structural modification of cutin due to the infection. Cutin is chemically stable and resistant to decomposition. It is composed of ester-bound monomers; however, it is unknown if an ordered organization of the entire polymer exists [41]. During pathogen-plant interactions, certain fungal and bacterial phytopathogens are known to secrete cutinases capable of depolymerizing cutin facilitating the infection of the pathogens [42]. The expression of cutinase is activated by plant components such as fatty acids of the cuticle acting as signals for recognition by pathogen as shown for Botrytis cinerea conidia incubated on a fruit apple wax-coated surface to mimic the properties of natural plant surfaces [43]. The reduction in methylene 'chains' length confirmed the action of cutinases produced by B. cinerea [42]. In contrast, tomato fruit treated with the highest PBPs dose $(4.8 \mathrm{mg} / \mathrm{mL})$ exhibited structural integrity of cutin. As the fruit cuticle plays a key role in resistance to biotic and abiotic stresses, its integrity allows fruit quality to be maintained after harvesting. The inner pulp layers' spectra (FT-IR and FT-Raman) highlighted structural changes in the pectin and protein components due to the infection and PBP treatment. In infected tomato fruits, the spectral profile was dramatically changed. In particular, the FT-IR bands of pectin at $1723 \mathrm{~cm}^{-1}$ ( $\mathrm{C}=\mathrm{O}$ stretching of ester), $1595 \mathrm{~cm}^{-1}$ and $1407 \mathrm{~cm}^{-1}$ (COO ${ }^{-}$asymmetric and symmetric stretching, respectively), $1237 \mathrm{~cm}^{-1}$ (C-O stretching) markedly decreased. Raman spectra confirmed this trend. By semi-quantitative evaluation of the region using peak fitting (Figure 12), the percent area at $1587 \mathrm{~cm}^{-1}$ was significantly decreased by $11 \%$ compared with $38 \%$ of the control. Particularly notable was the absence of the band at $1723 \mathrm{~cm}^{-1}$. In support of this outcome, we find that the degradation of pectin by $B$. cinerea results from several enzymes, including pectin methylesterase [44]. As a consequence of PBP treatment, we obtained an increase in the pectin region and, in particular, the percentage of band area at $1591 \mathrm{~cm}^{-1}$ was $45 \%$.

There was only a minor difference between control and treated with PBPs for the protein region, whereas a significant increase in the infected tomato was found. However, the protein contribution of the fungal mycelium cannot be excluded.

In the case of phenolic compounds, the percentage area at $1515 \mathrm{~cm}^{-1}$ was $4.5 \%$ in both control and infected plants; therefore, no phenolic accumulation is shown in infected tomatoes compared with the control. Therefore, it is possible to assume that $B$. cinerea does not apparently affect the phenylpropanoid pathway. In contrast, in PBP treatment, no band was detected in the IR spectrum, and only a weak band was detected at $1603 \mathrm{~cm}^{-1}$ in the Raman spectrum (Figure 11). In the same spectrum, carotenoid bands (1525, 1157 and $1006 \mathrm{~cm}^{-1}$ ) almost disappeared. Similarly, carotenoid contents of bean plants decreased by $28.3 \%$ and $35 \%$ during the 8 th and 12 th day after infection [45]. A sensible reduction of carotenoids (mainly lycopene and carotenoids) was observed after a prolonged exposition of human skin to UV irradiation [46], indicating a particular time response to oxidative 
stress, thus confirming the protective role of these compounds induced by the presence of PBPs against the fungal attack.

\section{Conclusions}

Cyanobacteria are microorganisms with biological potential for high $\mathrm{CO}_{2}$ fixation efficiency and production of biomedicinals but are also useful for improving the quality of fruits in post-harvest and controlling fungal diseases. Efficient applications of cyanobacteria and their extracts have been reported in agricultural practices to effectively manage pests and reduce global warming by decreasing $\mathrm{CO}_{2}$ gas emission [47]. Cyanobacteria produce an abundance of proteins, many bioactive compounds such as beta-carotene, and PBPs with a range of antifungal activity. Global regulations for plant disease control have changed and now encourage the use of natural alternative means to synthetic pesticides. Our studies have shown that cyanobacteria utilization could be considered for pest management and as a biotechnological challenge for optimization of protein production in the near future. However, more experimental work is required to optimize cyanobacterial cultivation parameters including organismal strain, temperature, culture density or biomass production, the choice of culture media, and the extraction process in order to maximize the yield of PBPs as natural products.

Supplementary Materials: The following are available online at https:/ /www.mdpi.com/article/10 .3390/horticulturae7080210/s1. Figure S1. Anabaena minutissima BEA 0300B: microphoto, $40 \times$ (left) and cultivation in polypropylene tanks under an outdoor greenhouse (right) at the Spanish Bank of Algae BEA (Canary Islands, Spain).

Author Contributions: Conceptualization, H.R., R.R. and O.F.; methodology, H.R., O.F., A.M.Q. and M.D.F.; formal analysis and data curation, H.R., R.R., O.F. and M.D.F.; writing-original draft preparation, H.R.; writing — review and editing, R.R., O.F., M.D.F. and A.M.Q.; project administration and funding acquisition, A.M.Q. and R.R. All authors have read and agreed to the published version of the manuscript.

Funding: This research was funded by the European Territorial Cooperation Program PCT-MAC 2014-2020 through project REBECA (MAC/1.1a/060) and the University of Bologna (RFO 2020).

Institutional Review Board Statement: Not applicable.

Informed Consent Statement: Not applicable.

Acknowledgments: The authors wish to thank Angela Finestrelli (Department of Agricultural and Food Sciences, University of Bologna, Italy) for technical support in the in vitro experiments.

Conflicts of Interest: The authors declare no conflict of interest.

\section{References}

1. Dean, R.; Van Kan, J.A.L.; Pretorius, Z.A.; Hammond-Kosack, K.E.; Di Pietro, A.; Spanu, P.D.; Rudd, J.J.; Dickman, M.; Kahmann, R.; Ellis, J.; et al. The Top 10 fungal pathogens in molecular plant pathology. Mol. Plant Pathol. 2012, 13, 414-430. [CrossRef] [PubMed]

2. Elad, Y.; Vivier, M.; Fillinger, S. Botrytis, the good, the bad and the ugly. In Botrytis-The Fungus, the Pathogen and Its Management in Agricultural Systems; Fillinger, S., Elad, Y., Eds.; Springer: Cham, Switzerland, 2015; pp. 1-15.

3. Mari, M.; Guizzardi, M.; Brunelli, M.; Folchi, A. Postharvest biological control of grey mould (Botrytis cinerea pers.: Fr.) on fresh-market tomatoes with Bacillus amyloliquefaciens. Crop Prot. 1996, 15, 699-705. [CrossRef]

4. Dik, A.J.; Elad, Y. Comparison of antagonists of Botrytis cinerea in greenhouse-grown cucumber and tomato under different climatic conditions. Eur. J. Plant Pathol. 1999, 105, 123-137. [CrossRef]

5. Nakajima, M.; Akutsu, K. Virulence factors of Botrytis cinerea. J. Gen. Plant Pathol. 2014, 80, 15-23. [CrossRef]

6. Blanco-Ulate, B.; Labavitch, J.M.; Vincenti, E.; Powell, A.L.T.; Cantu, D. Hitting the wall: Plant cell walls during Botrytis cinerea infections. In Botrytis_-The Fungus, the Pathogen and Its Management in Agricultural Systems; Fillinger, S., Elad, Y., Eds.; Springer: Cham, Switzerland, 2016; pp. 361-386.

7. Hahn, M. The rising threat of fungicide resistance in plant pathogenic fungi: Botrytis as a case study. J. Chem. Biol. 2014, 7, 133-141. [CrossRef]

8. Tyagi, R.; Kaushik, B.D.; Kumar, J. Antimicrobial activity of some cyanobacteria. In Microbial Diversity and Biotechnology in Food Security; Kharwar, R., Upadhyay, R., Dubey, N., Raghuwanshi, R., Eds.; Springer: New Delhi, India, 2014; pp. 463-470. 
9. Silva-Stenico, M.E.; Kaneno, R.; Zambuzi, F.A.; Vaz, M.G.M.V.; Alvarenga, D.O.; Fiore, M.F. Natural products from cyanobacteria with antimicrobial and antitumor activity. Curr. Pharm. Biotechnol. 2014, 14, 820-828. [CrossRef]

10. Soltani, N.; Khavari-Nejad, R.A.; Yazdi, M.T.; Shokravi, S.; Fernández-Valiente, E. Screening of soil cyanobacteria for antifungal and antibacterial activity. Pharm. Biol. 2005, 43, 455-459. [CrossRef]

11. Alsenani, F.; Tupally, K.R.; Chua, E.T.; Eltanahy, E.; Alsufyani, H.; Parekh, H.S.; Schenk, P.M. Evaluation of microalgae and cyanobacteria as potential sources of antimicrobial compounds. Saudi Pharm. J. 2020, 28, 1834-1841. [CrossRef]

12. Garcia-Pichel, F. Cyanobacteria. In Encyclopedia of Microbiology, 3rd ed.; Schaechter, M., Ed.; Academic Press: San Diego, CA, USA, 2009; pp. 107-124.

13. Prasanna, R.; Chaudhary, V.; Gupta, V.; Babu, S.; Kumar, A.; Singh, R.; Shivay, Y.S.; Nain, L. Cyanobacteria mediated plant growth promotion and bioprotection against Fusarium wilt in tomato. Eur. J. Plant Pathol. 2013, 136, 337-353. [CrossRef]

14. Righini, H.; Baraldi, E.; García Fernández, Y.; Martel Quintana, A.; Roberti, R. Different antifungal activity of Anabaena sp., Ecklonia sp., and Jania sp. against Botrytis cinerea. Mar. Drugs 2019, 17, 299. [CrossRef] [PubMed]

15. Righini, H.; Somma, A.; Cetrullo, S.; D’Adamo, S.; Flamigni, F.; Martel Quintana, A.; Roberti, R. Inhibitory activity of aqueous extracts from Anabaena minutissima, Ecklonia maxima and Jania adhaerens on the cucumber powdery mildew pathogen in vitro and in vivo. J. Appl. Phycol. 2020, 32, 3363-3375. [CrossRef]

16. Prasanna, R.; Nain, L.; Tripathi, R.; Gupta, V.; Chaudhary, V.; Middha, S.; Joshi, M.; Ancha, R.; Kaushik, B.D. Evaluation of fungicidal activity of extracellular filtrates of cyanobacteria-Possible role of hydrolytic enzymes. J. Basic Microbiol. 2008, 48, 186-194. [CrossRef] [PubMed]

17. Radhakrishnan, B.; Prasanna, R.; Jaiswal, P.; Nayak, S.; Dureja, P. Modulation of biocidal activity of Calothrix sp. and Anabaena sp. by environmental factors. Biologia 2009, 64, 881-889. [CrossRef]

18. Righini, H.; Francioso, O.; Di Foggia, M.; Martel Quintana, A.; Roberti, R. Preliminary study on the activity of phycobiliproteins against Botrytis cinerea. Mar. Drugs 2020, 18, 600. [CrossRef]

19. Chalmers, J.M.; Griffiths, P.R. (Eds.) Handbook of Vibrational Spectroscopy. Theory and Instrumentation; Wiley \& Sons: Chichester, UK, 2002; Volume 1, 932p.

20. Andersen, R.A. Algal Culturing Techniques, 1st ed.; Elsevier: Amsterdam, The Netherlands, 2005; p. 578.

21. Roberti, R.; Galletti, S.; Burzi, P.L.; Righini, H.; Cetrullo, S.; Perez, C. Induction of defence responses in zucchini (Cucurbita pepo) by Anabaena sp. water extract. Biol. Control 2015, 82, 61-68. [CrossRef]

22. Pane, C.; Villecco, D.; Roscigno, G.; De Falco, E.; Zaccardelli, M. Screening of plant-derived antifungal substances useful for the control of seedborne pathogens. Arch. Phytopathol. Plant Prot. 2013, 46, 1533-1539. [CrossRef]

23. Coates, J. Interpretation of Infrared Spectra, A Practical Approach. In Encyclopedia of Analytical Chemistry; Meyers, R.A., Ed.; John Wiley \& Sons Ltd.: Chichester, UK, 2006; pp. 10815-10837.

24. Giordano, M.; Kansiz, M.; Heraud, P.; Beardall, J.; Wood, B.; McNaughton, D. Fourier transform infrared spectroscopy as a novel tool to investigate changes in intracellular macromolecular pools in the marine microalga Chaetoceros muellerii (Bacillariophyceae). $J$. Phycol. 2001, 37, 271-279. [CrossRef]

25. Rao, C.N.R. Chemical Applications of Infrared Spectroscopy; Academic Press, Inc.: New York, NY, USA; London, UK, $1963 ;$ p. 681.

26. Stehfest, K.; Toepel, J.; Wilhelm, C. The application of micro-FTIR spectroscopy to analyze nutrient stress-related changes in biomass composition of phytoplankton algae. Plant Physiol. Biochem. 2005, 43, 717-726. [CrossRef]

27. Tinti, A.; Di Foggia, M.; Taddei, P.; Torreggiani, A.; Dettin, M.; Fagnano, C. Vibrational study of auto-assembling oligopeptides for biomedical applications. Proc. J. Raman Spectrosc. 2008, 39, 250-259. [CrossRef]

28. Heredia-Guerrero, J.A.; Bemtez, J.J.; Dommguez, E.; Bayer, L.S.; Cingolani, R.; Athanassiou, A.; Heredia, A. Infrared spectroscopy as a tool to study plant cuticles. Spectrosc. Eur. 2016, 28, 10-13.

29. Szymanska-Chargot, M.; Zdunek, A. Use of FT-IR spectra and PCA to the bulk characterization of cell wall residues of fruits and vegetables along a fraction process. Food Biophys. 2013, 8, 29-42. [CrossRef]

30. Szymańska-Chargot, M.; Chylińska, M.; Pieczywek, P.M.; Rösch, P.; Schmitt, M.; Popp, J.; Zdunek, A. Raman imaging of changes in the polysaccharides distribution in the cell wall during apple fruit development and senescence. Planta 2016, 243, 935-945. [CrossRef]

31. Synytsya, A.; Čopíková, J.; Matějka, P.; Machovič, V. Fourier transform Raman and infrared spectroscopy of pectins. Carbohydr. Polym. 2003, 54, 97-106. [CrossRef]

32. España, L.; Heredia-Guerrero, J.A.; Segado, P.; Benítez, J.J.; Heredia, A.; Domínguez, E. Biomechanical properties of the tomato (Solanum lycopersicum) fruit cuticle during development are modulated by changes in the relative amounts of its components. New Phytol. 2014, 202, 790-802. [CrossRef]

33. Heredia-Guerrero, J.A.; Benítez, J.J.; Domínguez, E.; Bayer, I.S.; Cingolani, R.; Athanassiou, A.; Heredia, A. Infrared and Raman spectroscopic features of plant cuticles: A review. Front. Plant Sci. 2014, 5, 1-14. [CrossRef]

34. Eckert, J.W.; Sommer, N.F. Control of diseases of fruits and vegetables by post-harvest treatment. Annu. Rev. Phytopathol. 1967, 5, 391-428. [CrossRef]

35. Kulik, M.M. The potential for using cyanobacteria (blue-green algae) and algae in the biological control of plant pathogenic bacteria and fungi. Eur. J. Plant Pathol. 1995, 101, 585-599. [CrossRef]

36. Mahawar, H.; Prasanna, R.; Gogoi, R. Elucidating the disease alleviating potential of cyanobacteria, copper nanoparticles and their interactions in Fusarium solani challenged tomato plants. Plant Physiol. Rep. 2019, 24, 533-540. [CrossRef] 
37. Righini, H.; Francioso, O.; Di Foggia, M.; Prodi, A.; Martel Quintana, A.; Roberti, R. Tomato seed biopriming with water extracts from Anabaena minutissima, Ecklonia maxima and Jania adhaerens as a new agro-ecological option against Rhizoctonia solani. Sci. Hortic. 2021, 281, 109921. [CrossRef]

38. Najdenski, H.M.; Gigova, L.G.; Iliev, I.I.; Pilarski, P.S.; Lukavský, J.; Tsvetkova, I.V.; Ninova, M.S.; Kussovski, V.K. Antibacterial and antifungal activities of selected microalgae and cyanobacteria. Int. J. Food Sci. Technol. 2013, 48, 1533-1540. [CrossRef]

39. McKay, M.J.; Afrose, F.; Koeppe, R.E.; Greathouse, D.V. Helix formation and stability in membranes. Biochim. Biophys. Acta Biomembr. 2018, 1860, 2108-2117. [CrossRef] [PubMed]

40. Agrios, G. Plant Pathology, 5th ed.; Elsevier Academic Press: San Diego, CA, USA, 2005; p. 922.

41. Fich, E.A.; Segerson, N.A.; Rose, J.K.C. The plant polyester cutin: Biosynthesis, structure, and biological roles. Annu. Rev. Plant Biol. 2016, 67, 207-233. [CrossRef] [PubMed]

42. Ziv, C.; Zhao, Z.; Gao, Y.G.; Xia, Y. Multifunctional roles of plant cuticle during plant-pathogen interactions. Front. Plant Sci. 2018, 9, 1088. [CrossRef] [PubMed]

43. Leroch, M.; Kleber, A.; Silva, E.; Coenen, T.; Koppenhöfer, D.; Shmaryahu, A.; Valenzuela, P.D.T.; Hahn, M. Transcriptome profiling of Botrytis cinerea conidial germination reveals upregulation of infection-related genes during the prepenetration stage. Eukaryot. Cell 2013, 12, 614-626. [CrossRef] [PubMed]

44. Wubben, J.P.; Ten Have, A.; Van Kan, J.A.L.; Visser, J. Regulation of endopolygalacturonase gene expression in Botrytis cinerea by galacturonic acid, ambient $\mathrm{pH}$ and carbon catabolite repression. Curr. Genet. 2000, 37, 152-157. [CrossRef] [PubMed]

45. Lobato, A.K.S.; Gonçalves-Vidigal, M.C.; Vidigal Filho, P.S.; Andrade, C.A.B.; Kvitschal, M.V.; Bonato, C.M. Relationships between leaf pigments and photosynthesis in common bean plants infected by anthracnose. N. Z. J. Crop Hortic. Sci. 2010, $38,29-37$. [CrossRef]

46. Darvin, M.E.; Gersonde, I.; Albrecht, H.; Sterry, W.; Lademann, J. In vivo Raman spectroscopic analysis of the influence of UV radiation on carotenoid antioxidant substance degradation of the human skin. Laser Phys. 2006, 16, 833-837. [CrossRef]

47. Chittora, D.; Meena, M.; Barupal, T.; Swapnil, P. Cyanobacteria as a source of biofertilizers for sustainable agriculture. Biochem. Biophys. Rep. 2020, 22, 100737. [CrossRef] 